\title{
The Metabolism of Starch, Glucose, Amino Acids, Purines, Pyrimidines and Bacteria by the Rumen Ciliate Entodinium simplex
}

\author{
By G. S. COLEMAN \\ Biochemistry Department, A.R.C. Institute of Animal Physiology, \\ Babraham, Cambridge
}

(Accepted for publication I2 January 1972)

SUMMARY

Washed suspensions of Entodinium simplex grown in vitro and incubated anaerobically engulfed all the types of bacteria tested. At high bacterial densities Klebsiella aerogenes and Proteus mirabilis, two bacteria normally present in the growth medium, were taken up most rapidly. Entodinium simplex utilized bacterial amino acids for the synthesis of protein and no evidence was obtained for appreciable synthesis of protein from carbohydrate. No interconversion of amino acids occurred. Free and bacterial adenine, guanine and uracil were incorporated into protozoal nucleic acid: uracil was partially converted into cytosine. Free amino acids and glucose were taken up by the protozoa by two mechanisms, one predominant at high concentrations and the other at low concentrations. Glucose was incorporated, in intact protozoa, into both polysaccharide and bacteria and glucose had to be taken up by the protozoa before it was incorporated into the bacteria.

\section{INTRODUCTION}

Although Entodinium simplex has been grown in vitro (Jarvis \& Hungate, I968; Coleman, r 969 a) studies have only been made of its lipid metabolism. Gutierrez, Williams, Davis \& Warwick (1962) and Williams, Gutierrez \& Davis (1963) showed that E. simplex concentrated fatty acids, and that tributyrin stimulated gas production by washed suspensions of this protozoon.

However, the metabolism of Entodinium caudatum has been more extensively investigated and no evidence found for the biosynthesis from carbohydrate of amino acids, purines or pyrimidines, or for the interconversion of these compounds. There was no extensive catabolism of amino acids, although leucine, isoleucine and valine were oxidatively deaminated to form isovaleric, $\alpha$-methyl butyric and isobutyric acids respectively (Coleman, $1967 a, b$, 1968, I969b). Entodinium caudatum rapidly engulfed particulate matter and it is likely that this protozoon obtains the amino acids it requires for protein synthesis from bacteria. The maximum rate of uptake was approximately 200 bacteria/min and each protozoon contained ${ }_{10}{ }^{4}$ Escherichia coli when completely filled with this bacterium (Coleman, I964; Coleman \& Hall, 1969).

The present paper describes studies with Entodinium simplex which are similar to those made with $E$. caudatum and shows that there are similarities between the two species. 


\section{METHODS}

Source of protozoa. Entodinium simplex was first isolated from the rumen 5 years ago by the method described previously (Coleman, 1969a) and has since been maintained in culture by the method described below. The experiments were carried out throughout this period.

Culture medium. The medium consisted of $60 \mathrm{ml}$ mineral salt solution, I $2 \mathrm{ml} 5 \%(\mathrm{w} / \mathrm{v})$ $\mathrm{NaHCO}_{3}, 0.9 \mathrm{ml} 2 \%$ (w/v) L-cysteine $\mathrm{HCl}$ (neutralized immediately before use) and $9 \mathrm{ml}$ autoclaved rumen fluid (ARF; Coleman, 1969a), contained in a I00 $\mathrm{ml}$ centrifuge tube; $\mathrm{CO}_{2}$ was bubbled vigorously through the complete medium for 3 min and the tubes immediately stoppered with a rubber bung. The mineral salts solution contained $(\mathrm{g} / 100 \mathrm{ml})$ : $\mathrm{K}_{2} \mathrm{HPO}_{4}, 0.49 ; \mathrm{KH}_{2} \mathrm{PO}_{4}, 0.38 ; \mathrm{NaCl}, 0.049 ; \mathrm{CaCl}_{2}$ (dried), $0.0035 ; \mathrm{MgSO}_{4} \cdot 7 \mathrm{H}_{2} \mathrm{O}, 0.007$.

Cultural conditions. A I $5 \%$ (w/v) aqueous suspension of 'stone ground' wholemeal flour (W. Prewett Ltd, Stone Flour Mills, Horsham, Sussex) $(0.5 \mathrm{ml})$ and $5 \mathrm{mg}$ dried grass (Coleman, 1960) were added daily and the cultures were then gassed with $\mathrm{CO}_{2}$, sealed with a rubber bung and incubated at $39{ }^{\circ} \mathrm{C}$. Twice each week the contents of each tube were mixed and half was poured into another tube. The medium in each tube was then made up to the original volume with fresh medium and wholemeal flour and grass added before gassing each tube with $\mathrm{CO}_{2}$.

Washed suspensions of protozoa. These were prepared as described by Coleman $(1969 b)$, except that the mineral salt solution $\mathrm{D}$ used contained $(\mathrm{g} / \mathrm{I} / 0 \mathrm{ml}): \mathrm{K}_{2} \mathrm{HPO}_{4}, 0.64 ; \mathrm{KH}_{2} \mathrm{PO}_{4}$, $0.55 ; \mathrm{NaCl}, 0.064 ; \mathrm{CaCl}_{2}$ (dried), $0.005 ; \mathrm{MgSO}_{4} \cdot 7 \mathrm{H}_{2} \mathrm{O}, 0.0 \mathrm{I}$. The protozoa were finally used as an inoculum to give a population density of $\mathrm{I}$ to $20 \times 10^{5} \mathrm{protozoa} / \mathrm{ml}$. Before use $2 \%(\mathrm{w} / \mathrm{v})$ L-cysteine hydrochloride (neutralized) solution was added ( $\mathrm{I} \mathrm{ml} / \mathrm{IO} \mathrm{ml}$ of suspension) and the whole bubbled vigorously with $95 \% \mathrm{~N}_{2}+5 \% \mathrm{CO}_{2}$. Unfortunately all preparations contained appreciable amounts of extraneous material, such as grass and husk from the wholemeal flour, which could not be removed.

Incubation. The medium consisted of 0.05 to $0.5 \mathrm{ml}\left[{ }^{14} \mathrm{C}\right]$ sugar, amino acid, purine or pyrimidine $(0.005$ to $\mathrm{I} \cdot 0 \mathrm{M}$ and $\mathrm{I} \cdot 0$ to $\mathrm{I} 0.0 \mu \mathrm{Ci} / \mathrm{ml})$ or ${ }^{14} \mathrm{C}$-labelled bacteria, 0 to $0.15 \mathrm{ml}$ ARF (Coleman, I969a), o to $0.06 \mathrm{ml}$ benzylpenicillin (25000 units $/ \mathrm{ml}$ ), 0 to $0.06 \mathrm{ml} \mathrm{I} \%(\mathrm{w} / \mathrm{v}$ ) neomycin sulphate, $\mathrm{I} \cdot 0 \mathrm{ml}$ protozoal suspension and o to $0.45 \mathrm{ml}$ salt solution $\mathrm{D}$, to give a final volume of $\mathrm{I} \cdot 5 \mathrm{ml}$. Experiments were carried,out in $4 \times 0.5$ inch thick-walled test tubes and after inoculation the contents were bubbled for I min with $95 \% \mathrm{~N}_{2}+5 \% \mathrm{CO}_{2}$, and the tube sealed with a rubber bung and incubated at $39^{\circ} \mathrm{C}$. The ARF, penicillin and neomycin were added only as indicated in the text.

Breakage of protozoa. At the end of the experiment the protozoa were centrifuged down and washed three times in salt solution $D$ on a bucket-head centrifuge for $30 \mathrm{~s}$ from starting (maximum speed equivalent to $200 \mathrm{~g}$ ). Under these conditions less than $0 . \mathrm{I} \%$ of any free bacteria were sedimented with the protozoa. The washed protozoa were suspended in $2 \mathrm{ml}$ salt solution $\mathrm{D}$ and then plated out to determined radioactivity or, in experiments to measure the viability of intracellular bacteria or determine the distribution of intracellular ${ }^{14} \mathrm{C}$, broken by sonication. The tube containing the protozoa was immersed, to the depth of the liquid in the tube, in a $80 \mathrm{kc} / \mathrm{s} 40 \mathrm{~W}$ ultrasonic cleaning bath (KG 80/I ; Kerry's, Chester Hall Lane, Basildon, Essex) until no intact protozoa were present as determined by microscopical examination. Although viable count measurements were made on this crude homogenate, it was usually centrifuged at $7000 \mathrm{~g}$ for $20 \mathrm{~min}$. The supernatant fluid from this centrifugation is hereafter referred to as the 'broken-cell supernatant fluid' and the pellet, after washing once, as the 'broken-cell pellet'. The residual bacteria (if any) were spun down from the 
first supernatant fluid obtained after removal of the protozoa and washed once at $2000 \mathrm{~g}$ for 15 min on an angle-head centrifuge.

${ }^{14} \mathrm{C}$-Volatile fatty acids. These were estimated as described by Coleman (1969 $b$ ).

Bacterial growth media and viable counts. See Coleman (1967b).

Total bacterial counts. The total number of bacteria in a washed bacterial suspension was estimated by counting an appropriate dilution in a Helber counting chamber of depth $0.02 \mathrm{~mm}$ and square size $0.0025 \mathrm{~mm}^{2}$.

Protozoal counts. The numbers of protozoa were estimated by the method of Coleman (1958). Only those protozoa which showed no signs of disintegration were counted.

Estimation of ${ }^{14} C$. This was done as described by Coleman (I969 b). The amount of a compound, such as an amino acid, that was incorporated by whole protozoa, or into the fraction sampled, was calculated from the known specific activity of the amino acid added initially. Similarly, the number of bacteria engulfed was calculated from the known specific activity (c.p.m./bacterium) of the bacterial suspension added initially. The position of ${ }^{14} \mathrm{C}-$ containing spots on chromatograms was determined by autoradiography and their relative ${ }^{14} \mathrm{C}$ contents by a multiple-flow chromatogram scanner (Baird \& Tatlock, Ltd, Chadwell Heath, Essex). ${ }^{14} \mathrm{CO}_{2}$ was determined by the method of Coleman (1956).

Fractionation of organisms. This was carried out as described by Coleman (1969 $b$ ). The hot TCA-soluble fraction, after removal of the TCA, was evaporated to dryness in a desiccator and further hydrolysed by one of the following methods. To liberate free purines and pyrimidines the fraction was treated with $72 \% \mathrm{HClO}_{4}$ for I h at $100{ }^{\circ} \mathrm{C}$ (Wyatt, I95I) and the $\mathrm{HClO}_{4}$ diluted with an equal volume of water before application to paper for chromatography in isopropanol $+\mathrm{HCl}$ (sp.gr. $\mathrm{I} \cdot \mathrm{I} 8)+\mathrm{H}_{2} \mathrm{O}(65+\mathrm{I} 7+\mathrm{I} 8$ by vol.). To liberate free glucose the fraction was heated at $100^{\circ} \mathrm{C}$ in $\mathrm{I} \cdot 0 \mathrm{~N}-\mathrm{H}_{2} \mathrm{SO}_{4}$ for $\mathrm{I} h$. When the solution was cool the acid was neutralized with $\mathrm{Ba}(\mathrm{OH})_{2}$ and, after removal of the resultant $\mathrm{BaSO}_{4}$, the solution was evaporated to dryness in a desiccator. Sugars were separated by chromatography in $n$ propanol + ethyl acetate $+\mathrm{H}_{2} \mathrm{O}(24+\mathrm{I} 3+7$ by vol. $)$.

Preparation of ${ }^{14} \mathrm{C}$-labelled starch grains. These were prepared as described by Coleman (1969b).

\section{RESULTS}

\section{Survival of washed Entodinium simplex suspensions}

Entodinium simplex was more susceptible to oxygen than E. caudatum and the method used for washed suspension experiments with the latter (Coleman 1969 $b$ ) had to be modified in that $0.2 \%(\mathrm{w} / \mathrm{v})$ L-cysteine hydrochloride (neutralized) was added to the protozoal suspension and $95 \% \mathrm{~N}_{2}+5 \% \mathrm{CO}_{2}$ bubbled through the complete medium after inoculation and before sealing the tube with a rubber bung. Under these conditions more than $70 \%$ of the protozoa survived for $5 \mathrm{~h}$, compared with less than $10 \%$ under the conditions used for E. caudatum.

To obtain good survival (greater than $70 \%$ ) of Entodinium simplex for $24 \mathrm{~h}$ it was essential to add 1000 units penicillin and $0.3 \mathrm{mg}$ rice starch $/ \mathrm{ml}$. The further addition of $400 \mu \mathrm{g}$ neomycin sulphate/ml had no effect on protozoal survival although it depressed bacterial growth. The addition of $10 \%(\mathrm{v} / \mathrm{v})$ autoclaved rumen fluid (ARF; Coleman, I969a), in the presence or absence of neomycin, improved the survival by about $10 \%$.

The type of carbohydrate added also influenced survival, although it was necessary to incubate for $48 \mathrm{~h}$ in the presence of penicillin, neomycin and autoclaved rumen fluid to obtain a clear effect. The survivals under these conditions were (relative to rice starch $=100 \%$ ): no added carbohydrate, I0\%; $0.04 \mathrm{M}$-sucrose, $17 \% ; 0.04 \mathrm{M}$-galactose, $19 \%$; 


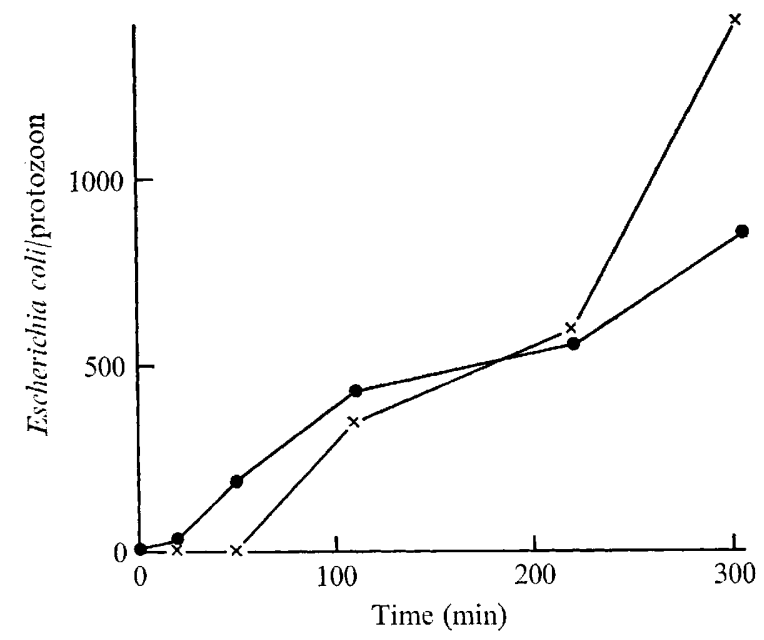

Fig. I

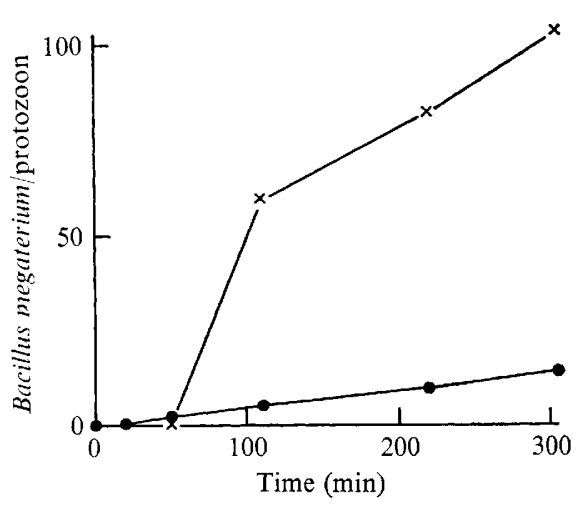

Fig. 2

Fig. I, 2. Time course for the engulfment and digestion of Escherichia coli (Fig. I; $\left.43 \times 10^{7} / \mathrm{ml}\right)$ and Bacillus megaterium (Fig. $2 ; 2.8 \times 10^{7} / \mathrm{ml}$ ) by Entodinium simplex $\left(3.7 \times 10^{4} / \mathrm{ml}\right)$ incubated anaerobically in salts medium. Bacteria found in protozoa; $x$, soluble materials from bacteria released into medium.

$0.04 \mathrm{M}$-glucose, $37 \% ; 0.7 \%(\mathrm{w} / \mathrm{v})$ soluble starch, $82 \% ; 0.04 \mathrm{M}-$ maltose, $92 \% ; 0.06 \%(\mathrm{w} / \mathrm{v})$ rice starch, $100 \%$. This pattern of survival is similar to that obtained with Entodinium caudatum (Coleman, I969b).

\section{The metabolism of bacteria}

Uptake of bacteria by Entodinium simplex was measured by the incorporation by the protozoa of ${ }^{14} \mathrm{C}$ from ${ }^{14} \mathrm{C}$-labelled bacteria of known specific activity. The ${ }^{14} \mathrm{C}$-labelled bacteria were prepared by overnight growth in medium in the presence of $\left[\mathrm{U}-{ }^{14} \mathrm{C}\right] \mathrm{glucose}$ or, when there was poor incorporation of ${ }^{14} \mathrm{C}$ from $\left[{ }^{14} \mathrm{C}\right]$ glucose, in the presence of $\left[8-{ }^{14} \mathrm{C}\right]-$ guanine. With Escherichia coli and Bacillus megaterium, which grew on glucose as sole source of carbon, the resultant bacteria were uniformly labelled with ${ }^{14} \mathrm{C}$ but with the others which required complex media the labelling, even from $\left[{ }^{14} \mathrm{C}\right]$-glucose, was not uniform. The bacteria were separated from the protozoa by differential centrifugation as described under Methods. With all the ${ }^{14} \mathrm{C}$-labelled bacteria used in these experiments less than $0.5 \%$ of the ${ }^{14} \mathrm{C}$ present was incorporated into the 'protozoal fraction' initially, or after incubation in the absence of protozoa. In the presence of protozoa the incorporation of ${ }^{14} \mathrm{C}$ into the protozoal fraction increased with time, although the number of bacteria found inside each protozoon after $5 \mathrm{~h}$ (calculated from the specific activity (c.p.m./bacterium) of the bacteria added initially) varied markedly between different bacterial species; e.g. I4 B. megaterium/ protozoon compared with $850 \mathrm{E}$. coli/protozoon (Fig. 2, I). There was also variation in the number of bacteria digested per bacterium found inside the protozoa, as calculated from the difference in the amount of ${ }^{14} \mathrm{C}$ present in the medium in the presence and absence of protozoa and the initial specific activity of the bacteria. With $E$. coli and $B$. megaterium the first products of digestion appeared in the medium after 50 and 30 min respectively, and after $5 \mathrm{~h}$ of incubation $1.7 \mathrm{E}$. coli and $7.0 \mathrm{~B}$. megaterium had been digested per bacterium present inside each protozoon (Fig. I, 2). This latter difference may not be genuine as the rate of digestion per bacterium might have been much lower in a protozoon that contained many bacteria. 


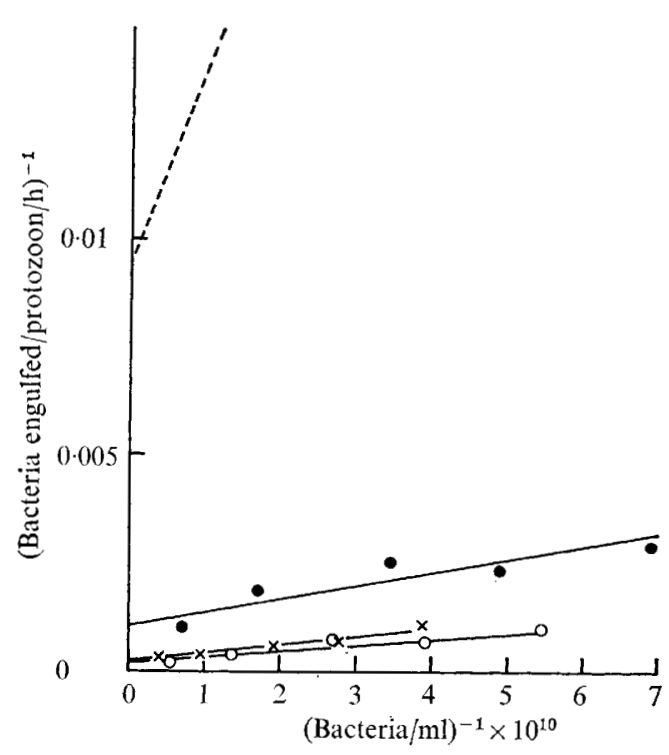

Fig. 3

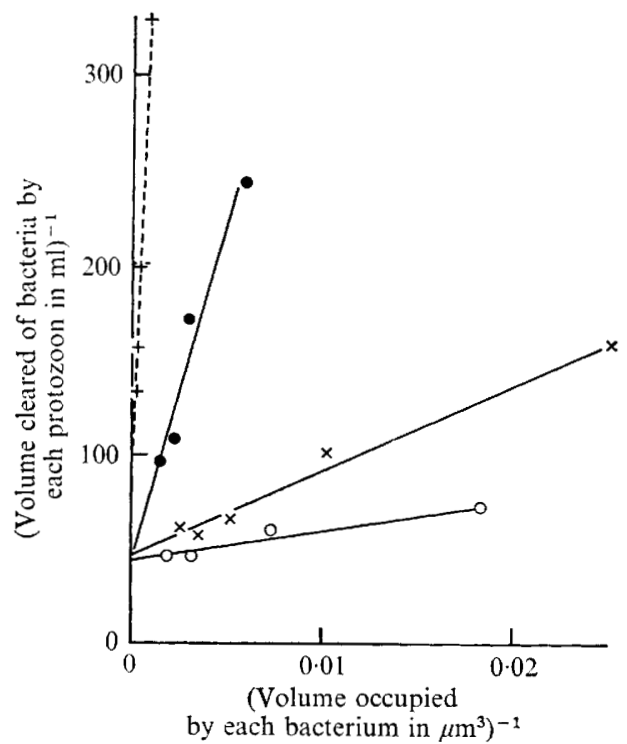

Fig. 4

Fig. 3, 4. Entodinium simplex $\left(1 \cdot 3 \times 10^{4}\right)$ was incubated anaerobically for $3 \mathrm{~h}$ with ${ }^{14} \mathrm{C}$-labelled bacteria and the uptake of ${ }^{14} \mathrm{C}$ into the protozoa measured. The number of bacteria engulfed was calculated from the ${ }^{14} \mathrm{C}$ present in the protozoa and the initial specific activity of the bacteria. The maximum number of bacteria engulfed/protozoon/h was obtained from Fig. 3 by extrapolation to the ordinate. The volume of medium cleared of bacteria was the product of the number of bacteria engulfed and the volume of medium initially occupied by each. The maximum volume of medium cleared of bacteria was obtained from Fig. 4 by extrapolation to the ordinate.,+----+ Bacillus megaterium; - Escherichia coli $\times \longrightarrow \times$, Proteus mirabilis; $\mathrm{O}_{-} \mathrm{O}$, Klebsiella aerogenes.

The uptake of bacteria was also sensitive to change in the $\mathrm{pH}$ value of the medium and was maximal at $\mathrm{pH} 7$ and decreased to nothing at $\mathrm{pH} 5$.

Comparison of the rates of engulfment of different bacterial species. All the species of bacteria tested (given in Table I) were taken up by Entodinium simplex. In order to compare the rates of uptake of different species measurements were made of the maximum rate of uptake over $3 \mathrm{~h}$ at infinite bacterial suspension density and of the volume of medium cleared of bacteria when they were present at infinitely low suspension density. The former measures differences in the rate at which a protozoon can engulf bacteria after which it does not have to swim and may depend on the size and shape of the bacteria. It was measured by extrapolation to the ordinate of a reciprocal plot of bacterial uptake against bacterial suspension density (Fig. 3). The latter measures a protozoon's ability to find, catch and engulf individual bacteria from a large volume of medium and may depend on the attraction between the bacterium and the protozoon. To measure this it was first necessary to calculate the volume of medium cleared of bacteria. This was the product of the number of bacteria engulfed and the volume $\left(\mu \mathrm{m}^{3}\right)$ occupied by each bacterium in the original suspension $\left(10^{12} /\right.$ number of bacteria/ml). As never more than $10 \%$ of the bacteria present were engulfed the error involved in using the volume originally occupied by each bacterium instead of the actual volume was small. The volume of medium cleared of bacteria at infinitely low suspension density was measured by extrapolation to the ordinate of a reciprocal plot of the volume cleared of bacteria against the volume occupied by each bacterium (Fig. 4). As it was only possible to compare five bacterial species in one experiment with one protozoal suspension, one bacterial species (Proteus mirabilis) was included in all experiments so that a comparison 
Table I. The engulfment of various bacterial species by Entodinium simplex

Suspensions of Entodinium simplex ( $1 \cdot 0$ to $6.0 \times 10^{4}$ protozoa $/ \mathrm{ml}$ ) were incubated anaerobically for $3 \mathrm{~h}$ with $\mathrm{I} \cdot 0$ to $140 \times 10^{81} \mathrm{C}$-labelled bacteria/ml, and uptake of ${ }^{14} \mathrm{C}$ into the protozoa measured. The number of bacteria engulfed was calculated from the ${ }^{14} \mathrm{C}$ present in the protozoa and the initial specific activity of the bacteria. The volumes of the bacteria are expressed relative to that of a single cell of Streptococcus faecalis $(=\mathrm{I})$ and were calculated from the packed cell volumes of a known number of bacteria. The maximum volume of bacteria is the product of the relative volume and the maximum number of bacteria engulfed. The maximum number of bacteria engulfed was calculated as shown in Fig. 3 and the text. The maximum volume of medium cleared of bacteria was calculated as shown in Fig. 4 and the text. The figures in brackets refer to similar experiments carried out with E. caudatum.

\section{Bacterium}

Bacillus megaterium

Butyrivibrio fibrisolvens

Escherichia coli

Klebsiella aerogenes

Proteus mirabilis

Streptococcus bovis

S. faecalis

Relative
volume
I0.8
$I \cdot 0$
$I \cdot 65$
$I \cdot 8$
$I \cdot 8$
$2 \cdot 0$
$I \cdot 0$

Maximum number of bacteria engulfed per protozoon $/ \mathrm{h}$

$105(520)$
2800
$900(2200)$
4100
$3700(4700)$
700
$2100(1430)$

Maximum volume
of bacteria
engulfed per
protozoon $/ \mathrm{h}$

I $130(5600)$
2800
$1530(3630)$
7400
$6700(8470)$
1400
$2100(1430)$

Maximum volume of medium cleared of bacteria per protozoon/h $\left(\mu \mathrm{m}^{3}\right)$

of uptakes was possible. Unfortunately, variation between experiments was impossible to eliminate as the suspensions contained variable amounts of particulate matter which, although it was larger than bacteria, could have altered the rate of engulfment of bacteria. The amount of starch visible inside the protozoa also varied between suspensions and would undoubtedly have altered the absolute rate of engulfment.

Table I and Fig. 3 and 4 show that although there was considerable variation in the maximum number of bacteria engulfed/h (as measured over a $3 \mathrm{~h}$ period) there was less variation between species when the total volume of bacterial material engulfed was compared. The total volume of material was the product of the number of bacteria engulfed and the volume of each bacterium calculated from the packed-cell volume of a known number of bacteria. There was even less variation (less than 3.5 times) when the comparison was made on the basis of the volume of medium cleared of bacteria from an infinitely dilute suspension. However, there was obviously some protozoal selectivity in the engulfment of different species of bacteria and it is of interest that Proteus mirabilis and Klebsiella aerogenes, which are found in the protozoal culture medium, were taken up most rapidly on a number and 'volume of material engulfed' basis. It is also of interest that the two rumen bacteria Streptococcus bovis and Butyrivibrio fibrisolvens were not taken up markedly more rapidly than the other bacteria although on a 'volume cleared' basis $B$. fibrisolvens was the most rapidly engulfed. Attempts to measure competition between bacteria for engulfment by Entodinium simplex by the method used for E. caudatum (Coleman, I964), which involved measuring the effect of ${ }^{12} \mathrm{C}$-bacteria on the uptake of ${ }^{14} \mathrm{C}$ from a saturating suspension of ${ }^{14} \mathrm{C}$-Escherichia coli, were unsuccessful. With Entodinium simplex it was not possible to saturate the engulfment mechanism with Escherichia coli at a usable suspension density. However, results for the engulfment of bacteria by Entodinium caudatum by the methods used for E. simplex are shown in Table I. It is apparent both in terms of maximum rates and comparative rates between bacteria that both protozoa behaved similarly, except that the largest bacterium, Bacillus megaterium, was engulfed much more rapidly by the larger protozoon, E. caudatum. This suggests that the small E. simplex might have had difficulty in engulfing this bacterium. Fig. 4 shows that at low bacterial suspension densities the number of 
B. megaterium and Escherichia coli engulfed increased rapidly as the volume occupied by each bacterium decreased, whereas with $K$. aerogenes the number of bacteria engulfed was almost independent of suspension density. In contrast at high bacterial population densities the number of both $K$. aerogenes and $E$. coli engulfed was almost independent of suspension density. In considering these results it is important not to place too much reliance on the absolute values quoted, as for Entodinium caudatum, at least, this varied several-fold depending on how much rice starch the organism contained; starved protozoa engulfed bacteria most rapidly. The results quoted in Table I were for protozoa fed $\mathrm{I} 6 \mathrm{~h}$ previously and were therefore minimal values.

The viability and digestion of bacteria engulfed by Entodinium simplex. Approximately $10^{6}$ protozoa were allowed to engulf ${ }^{14} \mathrm{C}$-labelled bacteria from a suspension of $10^{7}$ to $10^{10}$ bacteria $/ \mathrm{ml}$. At the beginning and after I $\mathrm{h}$ the protozoa were washed free of the suspension medium and the ${ }^{14} \mathrm{C}$ content of the protozoa and the bacteria-free supernatant determined. The number of viable bacteria was estimated in the medium, in washed intact protozoa and in these same protozoa broken by sonication. The difference between these last two counts gave the number of viable bacteria present inside the protozoa. Under the conditions used, sonication had no effect on the viability of the test bacteria. The total number of bacteria present inside the protozoa and the number that had been digested and their contents released into the medium was measured as described above. In one experiment where Escherichia coli was used as the test bacterium only $4.4(6 \cdot 2-\mathrm{I} \cdot 8)$ extra, viable bacteria, compared with ${ }^{14} \mathrm{C}$ from 490 bacteria, were found inside each protozoon after incubation, so that less than $\mathrm{I} \%$ of the engulfed bacteria were still viable. Soluble ${ }^{14} \mathrm{C}$ from 150 bacteria was present in the medium. On incubation with other bacteria for $\mathrm{I} h$ the proportion of the engulfed bacteria still viable, and the ratio of ${ }^{14} \mathrm{C}$ released into the medium over the ${ }^{14} \mathrm{C}$ present in the protozoa, were for Klebsiella aerogenes, $0 \%, 0.25$; Staphylococcus aureus, $5 \%, 0.65$; Serratia marcescens, 45 to $80 \%$, 0.10; Bacillus subtilis, $0 \%$, 0; Proteus mirabilis, $65 \%$, 0.18; $P$. vulgaris, $40 \%,{ }^{\circ} \cdot{ }_{5}$; Streptococcus faecalis, $0 \%, 0.35$. As with Entodinium caudatum it is apparent that the rate of killing is not related to Gram reaction or cell shape and that there was wide variation amongst the Enterobacteriaceae.

\section{The metabolism of $\left[{ }^{14} \mathrm{C}\right]$ amino acid-labelled Escherichia coli}

As Entodinium caudatum does not metabolize extensively the amino acids of bacterial protein (Coleman, $1967 b$ ) it was of interest to investigate the fate of these amino acids in Entodinium simplex. The test bacterium used was Escherichia coli labelled with one $\left[{ }^{14} \mathrm{C}\right]-$ amino acid, by growth in the presence of that $\left[{ }^{14} \mathrm{C}\right]$ amino acid and such $\left[{ }^{12} \mathrm{C}\right]$ amino acids as were found by Roberts et al. (1955) or the present author to prevent the incorporation of ${ }^{14} \mathrm{C}$ into other amino acids. Washed suspensions of these bacteria were incubated anaerobically with Entodinium simplex in the presence or absence in the medium of the ${ }^{12} \mathrm{C}$-form of the amino acid. ${ }^{14} \mathrm{C}$ was taken up by the protozoa under both conditions, but the presence of the ${ }^{12} \mathrm{C}$-form (0.0I M) of the amino acid decreased the incorporation of ${ }^{14} \mathrm{C}$ into the protozoa by $15 \%$ with alanine, $5 \%$ with arginine, $23 \%$ with glutamic acid, $31 \%$ with glycine, $25 \%$ with leucine, $26 \%$ with phenylalanine and $16 \%$ with proline. No evidence was obtained for the existence of two groups of amino acids with either no, or a very marked, effect on the incorporation of ${ }^{14} \mathrm{C}$, as was found with $E$. caudatum (Coleman, ${ }^{1967 b}$ ). Of the ${ }^{14} \mathrm{C}$ that was incorporated, approximately two-thirds was present in the broken-cell supernatant fluid, of which $25 \%$ was present in the pool and about $70 \%$ in the protein. With all the amino acids tested, $\left[{ }^{14} \mathrm{C}\right]$ alanine, arginine, aspartic acid, glycine, glutamic acid, leucine, proline and serine, the only $\left[{ }^{14} \mathrm{C}\right]$ amino acid present after hydrolysis of the protein fractions from the broken-cell supernatant fluid or broken-cell pellet was that present initially in the bacteria. 
Table 2. Products of the metabolism of leucine and glutamic acid in Escherichia coli by Entodinium simplex

Protozoa were incubated anaerobically for $3 \mathrm{~h}$ in Conway units, in the presence of Escherichia coli labelled with $\left[{ }^{14} \mathrm{C}\right]$ leucine or $\left[{ }^{14} \mathrm{C}\right]$ glutamic acid. Products were measured in the external medium. ${ }^{14} \mathrm{CO}_{2}$ was estimated after the addition of $\mathrm{HCl}$, by the method of Coleman (1956). ${ }^{14} \mathrm{C}$-Volatile acid was the ${ }^{14} \mathrm{C}$ that was retained on a planchette in the presence of alkali but lost in the presence of acid. Non-volatile ${ }^{14} \mathrm{C}$-material was that which was retained on the planchette in the presence of acid. The quantities of these various products in the medium are expressed in mol/100 mol of carbon incorporated into the protozoa.

$\begin{array}{lrrr}\overbrace{\begin{array}{c}\text { Volatile } \\ \text { acid }\end{array}} & \mathrm{CO}_{2} \mathrm{C} \text { recovered in } & \begin{array}{c}\text { Non-volatile } \\ \text { material }\end{array} \\ {\left[\mathrm{U}-14^{14} \mathrm{C}\right] \text { Glutamic acid }} & \mathrm{I} & 4 & \mathrm{I} 10 \\ {\left[{\left.\mathrm{I}-{ }^{14} \mathrm{C}\right] \text { Glutamic acid }}_{\left[\mathrm{U}^{14} \mathrm{C}\right] \text { Leucine }}\right.} & \mathrm{I} & 20 & 72 \\ {\left[\mathrm{I}^{14} \mathrm{C}\right] \text { Leucine }} & 36 & 9 & 25 \\ & 0 & \mathrm{I} 50 & 67\end{array}$

Entodinium simplex did not catabolize amino acids extensively and less than $5 \%$ of the carbon of bacterial serine, aspartic acid or glutamic acid incorporated into the protozoa was converted to $\mathrm{CO}_{2}$, and less than $15 \%$ into 'volatile fatty acids' (compounds that were retained on a planchette in the presence of alkali but lost in the presence of acid). However, when bacteria labelled with $\left[{ }^{-1}-{ }^{14} \mathrm{C}\right]$ glutamic acid were used, the amount of ${ }^{14} \mathrm{C}$ liberated as $\mathrm{CO}_{2}$ increased four times, indicating that there was preferential loss of carbon atom one, possibly via the tricarboxylic acid cycle (Table 2). There was slightly more breakdown of leucine, isoleucine and valine to $\mathrm{CO}_{2}$ and there was a preferential loss of carbon atom one of leucine as $\mathrm{CO}_{2}$ (Table 2). The acid-volatile material produced from leucine was probably isovaleric acid, as was produced by $E$. caudatum (Coleman, $1967 b$ ), but insufficient material was formed to enable a firm identification to be made.

\section{Metabolism of $\left[{ }^{14} \mathrm{C}\right]$ purine or pyrimidine labelled Escherichia coli}

It was not possible to prepare Escherichia coli labelled in its nucleic acid with a single $\left[{ }^{14} \mathrm{C}\right]$ purine or pyrimidine (Coleman, 1968$)$. Growth of $E$. coli on a glucose-ammonia-salts medium plus $\left[8-{ }^{14} \mathrm{C}\right]$ guanine, in the presence of a saturated solution of $\left[{ }^{12} \mathrm{C}\right]$ adenine, produced bacteria in the nucleic acid of which $78 \%$ of the ${ }^{14} \mathrm{C}$ was present as guanine and $22 \%$ as adenine. On incubation for $4 \mathrm{~h}$ of a washed suspension of these bacteria with Entodinium simplex $48 \%$ of the ${ }^{14} \mathrm{C}$ in the bacteria that had been engulfed was released into the medium. Of that which was retained by the protozoa $46 \%$ was present in the pool and $20 \%$ in the hot TCA-soluble fraction of the broken-cell supernatant fluid. Of this $7 \mathrm{I} \%$ was present as $\left[{ }^{14} \mathrm{C}\right]$ guanine and $29 \%$ as $\left[{ }^{14} \mathrm{C}\right]$ adenine, suggesting that both were incorporated from bacterial nucleic acid. Similarly incubation with Escherichia coli, the nucleic acid of which contained $58 \%$ of its ${ }^{14} \mathrm{C}$ as cytosine and $42 \%$ as uracil, gave protozoa whose nucleic acid contained $48 \%$ of its ${ }^{14} \mathrm{C}$ as cytosine and $52 \%$ as uracil.

\section{Metabolism of $\left[{ }^{14} \mathrm{C}\right]$ starch ( glycogen) grains}

The metabolism by Entodinium simplex of $\left[{ }^{14} \mathrm{C}\right]$ starch grains from holotrich protozoa was investigated by incubation with washed suspensions in the absence of antibiotics for $8 \mathrm{~h}$, or in the presence of penicillin ( 1800 units $/ \mathrm{ml}$ ) and neomycin sulphate $(700 \mu \mathrm{g} / \mathrm{ml}$ ) for $23 \mathrm{~h}$, or by addition to a standard, growing protozoal culture containing bacteria (Table 3 ). Under all conditions over $70 \%$ of the protozoal ${ }^{14} \mathrm{C}$ was present in two fractions, the pool 


\section{Table 3. The metabolism of $\left[{ }^{14} \mathrm{C}\right]$ starch grains by Entodinium simplex}

Protozoa were incubated anaerobically in the presence of $0.9 \mu \mathrm{Ci}\left[{ }^{14} \mathrm{C}\right] \mathrm{starch}$ grains from holotrich protozoa. Tube 1 contained $10^{7}$ washed protozoa suspended in $1 \cdot 4 \mathrm{ml}$ salts medium and was incubated for $8 \mathrm{~h}$. Tube 2 contained $10^{7}$ washed protozoa suspended in $1.4 \mathrm{ml}$ salts medium containing 1800 units penicillin $\mathrm{G}$ and $700 \mu \mathrm{g}$ neomycin sulphate $/ \mathrm{ml}$ and was incubated for $23 \mathrm{~h}$. Tube 3 was $100 \mathrm{ml}$ standard protozoal culture, containing 25000 protozoa $/ \mathrm{ml}$, to which was added $\left[{ }^{14} \mathrm{C}\right]$ holotrich starch instead of wholemeal flour, and it was incubated for $23 \mathrm{~h}$. At the end of the experiment the protozoa were washed, broken by sonication and the supernatant fluid and pellet fractions separated by centrifugation. From Tube 3 the free bacteria were separated as described in Methods.

Radioactivity (percentage of ${ }^{14} \mathrm{C}$ added initially)

Soluble material in medium Bacteria

Cold TCA-soluble

Ethanol-soluble protein

Lipid

Hot TCA-soluble

Residual protein

\begin{tabular}{|c|c|c|c|c|c|c|}
\hline \multirow[b]{2}{*}{$\begin{array}{l}\text { Initial } \\
\text { starch }\end{array}$} & \multicolumn{2}{|c|}{$\begin{array}{c}\text { Tube I } \\
\text { I6.3 } \\
-\end{array}$} & \multicolumn{2}{|c|}{$\begin{array}{c}\text { Tube } 2 \\
7 \cdot 1 \\
-\end{array}$} & \multicolumn{2}{|c|}{$\begin{array}{c}\text { Tube } 3 \\
59.5 \\
3.5\end{array}$} \\
\hline & $\begin{array}{c}\text { Super- } \\
\text { natant } \\
\text { fluid }\end{array}$ & Pellet & $\begin{array}{l}\text { Super- } \\
\text { natant } \\
\text { fluid }\end{array}$ & Pellet & $\begin{array}{c}\text { Super- } \\
\text { natant } \\
\text { fluid }\end{array}$ & Pellet \\
\hline $4 \cdot 8$ & 3.9 & $2 \cdot 1$ & $I \cdot 6$ & 0.58 & 0.13 & 0.15 \\
\hline 0.2 & 0.08 & 0.04 & 0.04 & 0.02 & 0.02 & $0.0 \mathrm{I}$ \\
\hline 0.03 & 0.06 & 0.07 & 0.08 & 0.02 & 0.01 & $0.0 I$ \\
\hline 89.0 & 0.09 & $4 \cdot 3$ & $0.2 \mathrm{I}$ & $2 \cdot 8$ & 0.03 & 0.34 \\
\hline 0.22 & 0.20 & 0.47 & 0.07 & 0.10 & 0.03 & 0.05 \\
\hline
\end{tabular}

and the hot TCA-soluble fraction of the broken cell pellet. This latter fraction contained any unmetabolized starch grains, any protozoal granular polysaccharide and the intracellular bacteria.

The main object was to discover if Entodinium simplex was able to synthesize protein from carbohydrate. Unfortunately, the $\left[{ }^{14} \mathrm{C}\right]$ starch contained a small amount of protein $(0.22 \%)$ that was not removed by papain and any measurement of protein synthesis had to be made against this background. With washed suspensions of E. simplex, incubated in the presence of antibiotics, there was no evidence for any protein synthesis from carbohydrate, as only $0.17 \%$ of the initial ${ }^{14} \mathrm{C}$ was found in protein at the end of the incubation (tube 2 of Table 3). However, over $8 \mathrm{~h}$, in the absence of antibiotics, the amount of ${ }^{14} \mathrm{C}$ in protein increased to $0.67 \%$ (tube I of Table 3 ). In the growing protozoal culture (tube 3 of Table 3 ), where no attempt was made to remove bacteria, less than $\mathrm{I} \%$ of the added ${ }^{14} \mathrm{C}$ was recovered in the protozoa. The amount of ${ }^{14} \mathrm{C}$ present in the protozoal protein was less than $40 \%$ of that added initially as protein, although it accounted for $10 \%$ of the ${ }^{14} \mathrm{C}$ in the protozoa. Although these results are not conclusive, it is considered likely that E. simplex has little or no ability to synthesize protein from carbohydrate and that the increase in the ${ }^{14} \mathrm{C}$ in the protein fractions in the absence of antibiotics was due to the synthesis of bacterial protein. The strain of Klebsiella aerogenes found in cultures of entodinia (White, 1969) could synthesize all its amino acids from carbohydrate and may be the bacterium responsible.

\section{The metabolism of free amino acids}

All the free amino acids tested were taken up progressively over at least $4 \mathrm{~h}$. The rates of uptake of individual amino acids, measured over $3 \mathrm{~h}$ at $0.5 \mathrm{~mm}$ and expressed in $\mathrm{nmol} / 1 \mathrm{I}^{6}$ protozoa/h were: for L-alanine, Io; L-arginine, 65; L-glutamic acid, 24; glycine, 40; L-leucine, I 2 ; L-lysine, I6; L-methionine, I 2 ; L-proline, I9; L-serine, 50; and L-valine, I8. On a reciprocal plot of amino acid uptake against amino acid concentration there was a break in the curve at $2 \mathrm{~mm}$ with all the amino acids tested. Entodinium simplex therefore differs from E. caudatum 
(Coleman, 1967a) in that the amino acids cannot be divided into two groups based on their rates of uptake and the position of the break in the curve on the reciprocal plot. However, the existence of a break in the curve suggests that amino acids were taken up by two different mechanisms at low and high external concentrations. Of the ${ }^{14} \mathrm{C}$ taken up by the protozoa less than $10 \%$ appeared in the protein fractions and no attempt was made to determine the distribution between the amino acids; most of the remaining activity was present in the pool.

\section{Metabolism of free adenine, guanine and uracil}

These results were obtained with protozoa incubated with 0.03 to $0.08 \mathrm{M}-\left[{ }^{14} \mathrm{C}\right]$ purine or $\left[{ }^{14} \mathrm{C}\right]$ pyrimidine for up to $48 \mathrm{~h}$, in the absence of antibiotics or carbohydrates. The metabolic products were identified as described by Coleman (I968).

$\left[8-{ }^{14} \mathrm{C}\right]$ Adenine. This was incorporated ( $3 \%$, as adenine only) into the nucleic acid (hot TCA-soluble) fraction of the protozoal broken-cell supernatant fluid and pellet fractions. It was also metabolized $(75 \%)$ and released into the medium as $\left[{ }^{14} \mathrm{C}\right]$ xanthine and hypoxanthine in approximately equal amounts.

$\left[8-{ }^{14} \mathrm{C}\right]$ Guanine. This was incorporated (I \% as guanine only) into the protozoal nucleic acid. The remainder was metabolized to xanthine which was subsequently converted almost quantitatively to hypoxanthine. This contrasts with the results obtained with Entodinium caudatum (Coleman, 1968) where only 10 \% of the guanine was converted into hypoxanthine.

$\left[2-{ }^{14} \mathrm{C}\right]$ Uracil. ${ }^{14} \mathrm{C}$ from $\left[{ }^{14} \mathrm{C}\right]$ uracil was incorporated $(2 \%)$ into the nucleic acid of the protozoal broken-cell supernatant fluid and pellet fractions as cytosine $\left(47 \%\right.$ of $\left.{ }^{14} \mathrm{C}\right)$ and uracil $\left(53 \%\right.$ of $\left.{ }^{14} \mathrm{C}\right)$. Uracil was also metabolized to dihydrouracil and $5.6 \times 10^{4}$ protozoa incubated with $0.05 \mu \mathrm{mol}$ uracil converted $55 \%$ to dihydrouracil in $6 \mathrm{~h}$.

\section{Metabolism of $\left[{ }^{14} \mathrm{C}\right]$ bicarbonate}

${ }^{14} \mathrm{C}$ from $\left[{ }^{14} \mathrm{C}\right]$ bicarbonate was readily taken up by Entodinium simplex and the distribution within the cell was similar to that found previously for $E$. caudatum (Coleman, I964). In E. simplex (results for E. caudatum in brackets) $14 \%$ (I6\%) of the ${ }^{14} \mathrm{C}$ was present in the pool, $55 \%(65 \%)$ in the hot TCA-soluble fractions of the broken-cell pellet and $\mathrm{I}_{2} \%(\mathrm{I} 3 \%)$ in the protein fractions; less than I \% was present in the lipid fractions. After hydrolysis in $\mathrm{I} \cdot \mathrm{O} \mathrm{N}-\mathrm{HCl}$ for $\mathrm{I} \mathrm{h}$ at $100^{\circ} \mathrm{C}$ the hot TCA-soluble fraction of the broken-cell pellet contained one ${ }^{14} \mathrm{C}$-compound which, after chromatography in five solvents (Coleman, 1964), was tentatively identified as glucose. To confirm its identity the unknown material was chromatographed in $n$-propanol + ethyl acetate + water $(24+13+7$, by vol.) before and after treatment with glucose oxidase. As a result of enzyme action the original spot disappeared and was replaced by another which had the same $R_{F}$ as the spot produced from pure $\left[{ }^{14} \mathrm{C}\right] \mathrm{glucose}$ under the same conditions. The residual protein fractions contained $\left[{ }^{14} \mathrm{C}\right]$ alanine, aspartic acid and glutamic acid.

\section{Metabolism of $\left[{ }^{14} \mathrm{C}\right]$ glucose}

${ }^{14} \mathrm{C}$ from $\left[\mathrm{U}^{-14} \mathrm{C}\right] \mathrm{glucose}$ was readily taken up by Entodinium simplex and the distribution of ${ }^{14} \mathrm{C}$ between the major cell fractions, when the incorporation was carried out in the presence or absence of penicillin and neomycin, is shown in Table 4. These results show that during a $4 \mathrm{~h}$ incubation the antibiotics inhibited incorporation of ${ }^{14} \mathrm{C}$ into the protozoa by $67 \%$. The distribution of ${ }^{14} \mathrm{C}$ between the major cell fractions was similar under the two conditions, except that in the presence of the antibiotics there was less ${ }^{14} \mathrm{C}$ in the residual protein fraction of the broken-cell supernatant fluid ( $0.6 \%$ compared with $8 \%$ ) and more in the hot TCA-soluble fraction of the broken cell pellet ( $59 \%$ compared with $4 \mathrm{I} \%$ ). On hydrolysis, in $\mathrm{I} \cdot 0 \mathrm{~N}-\mathrm{HCl}$ for $\mathrm{I} \mathrm{h}$ at $100^{\circ} \mathrm{C}$, of this latter fraction prepared from protozoa incubated 


\section{Table 4. Distribution of ${ }^{14} \mathrm{C}$ in Entodinium simplex after the incorporation of $\left[U-{ }^{14} \mathrm{C}\right]$ glucose}

Protozoa $\left(8 \cdot 0 \times 10^{5}\right)$ were incubated anaerobically for $4 \mathrm{~h}$ in a salts solution with $0.45 \mathrm{~mm}-\left[\mathrm{U}_{-}{ }^{14} \mathrm{C}\right]-$ glucose (600000 c.p.m.) in the presence or absence of 1700 units penicillin $+670 \mu \mathrm{g}$ neomycin sulphate $/ \mathrm{ml}$. After incubation the washed protozoa were broken by sonication and the supernatant fluid and pellet fractions separated by centrifugation. These were further fractionated as described in Methods.

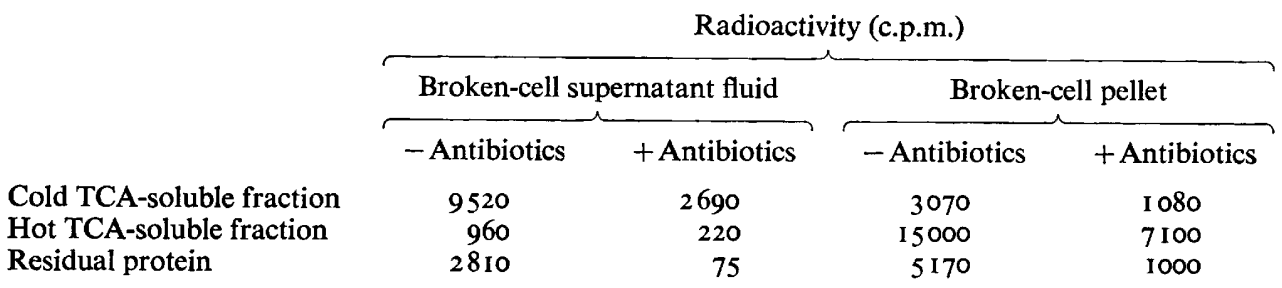

under either conditions, the only ${ }^{14} \mathrm{C}$ product was glucose (identified as described above). Nine per cent of the ${ }^{14} \mathrm{C}$ was found in the protein fractions in the presence of antibiotics, compared with $2 \mathrm{I} \%$ in their absence. ${ }^{14} \mathrm{C}$ from $\left[{ }^{14} \mathrm{C}\right]$ glucose was incorporated, principally as $\left[{ }^{14} \mathrm{C}\right]-$ glucose in the pool, under both conditions before ${ }^{14} \mathrm{C}$ appeared in the broken-cell pellet fraction. As there was no marked differential effect of the antibiotics on the distribution of ${ }^{14} \mathrm{C}$ within the protozoa, it is postulated that the antibiotics acted on the mechanism responsible for the uptake of glucose by the protozoa. The pellet fraction obtained after breakage of the protozoa contained the intracellular bacteria as well as the protozoal polysaccharide granules and any incorporation into this fraction could have been the result of bacterial metabolism. At least one of the bacteria present rapidly synthesized from free glucose a glucose-containing polysaccharide capsule (Coleman, $1969 b$ ), and the material in the hot TCA-soluble fraction of the broken-cell pellet would, therefore, have been of both bacterial and protozoal origin. Attempts to separate the protozoal polysaccharide from the bacteria by centrifugation through sucrose, by the method used for Entodinium caudatum (Coleman, 1969b), were unsuccessful and it was only possible to measure incorporation into the combined fractions. In an attempt to determine if some of the incorporation into this fraction was the result of bacterial metabolism and, if it was, whether the bacteria metabolized the glucose directly from the medium or only after incorporation by the protozoa, the following experiments were carried out.

Intact protozoa, and protozoa that had been broken by sonication so as to liberate intact their intracellular bacteria, were incubated with $\left[{ }^{14} \mathrm{C}\right]$ glucose. At the end of the incubation the protozoa were harvested normally, whereas the bacteria in the broken protozoal preparation were harvested and washed three times on the centrifuge at $7000 \mathrm{~g}$ before estimation of ${ }^{14} \mathrm{C}$. Comparison of the incorporation into the broken-cell pellet fraction of intact protozoa with incorporation into the liberated bacteria, showed that breakage of the protozoa before incubation increased the uptake by the bacteria by at least $85 \%$. This result shows that in intact protozoa the intracellular bacteria were not freely in contact with the external medium, because if they were, breakage should not alter the amount of ${ }^{14} \mathrm{C}$ incorporated. This also means that the bacteria would not be in contact with antibiotics added to the medium.

The bacteria, therefore, presumably metabolized glucose from the protozoal pool after it had been incorporated by the protozoa, although it was possible that the glucose still came directly from medium which diffused only slowly through the protozoal endoplasm to the surface of the bacteria. To distinguish between these possibilities, the differential effect of 


\section{Table 5. The effect of galactose on the incorporation of ${ }^{14} \mathrm{C}$ from $\left[U-{ }^{14} C\right]$ glucose by intact and broken Entodinium simplex}

Protozoa $\left(1 \cdot I \times 10^{5}\right)$, either intact or after breakage by sonication - see Methods, were incubated anaerobically for $3 \mathrm{~h}$ in the presence of $0.33 \mathrm{~mm}-\left[\mathrm{U}-{ }^{14} \mathrm{C}\right] \mathrm{glucose}(300000 \mathrm{c} . \mathrm{p} . \mathrm{m} . / \mathrm{ml})$ or $80 \mathrm{~mm}-$ $\left[\mathrm{U}-{ }^{14} \mathrm{C}\right]$ glucose $(300000$ c.p.m. $/ \mathrm{ml})$, in the presence or absence of $80 \mathrm{~mm}-\mathrm{D}$-galactose. At the end of the experiment the intact protozoa were washed, broken by sonication and separated by centrifugation into supernatant fluid and pellet fractions. Where the protozoa had been broken before incubation the tube was centrifuged at $7000 \mathrm{~g}$ for $20 \mathrm{~min}$ and the pellet obtained washed three times in mineral salts solution under the same conditions. This washed pellet was the same as the brokencell pellet obtained above except that the incubation with $\left[{ }^{14} \mathrm{C}\right] g l u c o s e$ occurred after, rather than before, breakage of the protozoa.

\begin{tabular}{|c|c|c|c|c|}
\hline Protozoal inoculum & $\begin{array}{c}\text { Glucose } \\
\text { concentration (mM) }\end{array}$ & Intact protozoa & $\begin{array}{c}\text { Broken-cell } \\
\text { supernatant fluid }\end{array}$ & Broken-cell pellet \\
\hline Intact & 0.33 & $13 \cdot 6^{*}$ & $11 \cdot 3^{*}$ & $14 \cdot 2^{*}$ \\
\hline Intact & 80 & $96^{*}$ & $100^{*}$ & $95^{*}$ \\
\hline Broken & 0.33 & - & - & $7 \cdot 0^{*}$ \\
\hline Broken & $80^{30}$ & - & - & $57^{*}$ \\
\hline
\end{tabular}

* Results are expressed relative to incorporation into fraction in absence of galactose at given glucose concentration $=\mathrm{I} 00$.

inhibitors on the uptake of ${ }^{14} \mathrm{C}$ from $\left[{ }^{14} \mathrm{C}\right]$ glucose into the protozoa and the intracellular bacteria, when inside the protozoa or liberated into the medium, was investigated. The addition to the incubation medium of penicillin ( 1700 units $/ \mathrm{ml}$ ) and neomycin sulphate $(670 \mu \mathrm{g} / \mathrm{ml})$ decreased incorporation into intact protozoa by $65 \%$, into the pellet fraction thereof by $6 \mathrm{I} \%$ and into the liberated bacteria by $75 \%$. If it is assumed for Entodinium simplex, as was shown conclusively with $E$. caudatum (Coleman, $1969 b$ ), that at any given external glucose concentration the inhibition of incorporation into the intracellular bacteria and the protozoal polysaccharide was the same, then the degree of inhibition into the intracellular bacteria in the present experiments was the same as that into the complete pellet fraction. This means that incorporation into the bacteria was more sensitive to the action of the antibiotics when the bacteria were free in the medium than when they were present inside the protozoa and provides further evidence that the bacteria were not freely in contact with the medium. The similarity in the degrees of inhibition of the incorporation of ${ }^{14} \mathrm{C}$ into intact protozoa and the intracellular bacteria suggests that in intact protozoa the only reaction inhibited by the antibiotics was the uptake of glucose by the protozoa. The bacteria then metabolized the glucose from a protozoal pool that contained no antibiotics. If the antibiotics had penetrated into the pool and inhibited the uptake of ${ }^{14} \mathrm{C}$ by the bacteria then the degree of inhibition of incorporation into intact protozoa would not be the same as that into the pellet fraction.

To confirm this conclusion, the effect of galactose, which is a different type of compound from the antibiotics, on the production of ${ }^{14} \mathrm{CO}_{2}$ and incorporation of ${ }^{14} \mathrm{C}$ from $\left[{ }^{14} \mathrm{C}\right]$ glucose by intact and broken protozoal preparations was investigated. Table 5 shows that, at low external $\left[{ }^{14} \mathrm{C}\right]$ glucose concentrations, galactose inhibited the incorporation of ${ }^{14} \mathrm{C}$ into the broken cell supernatant fluid and pellet fractions of the protozoa to a similar extent as the incorporation into bacteria liberated from the protozoa. The similarity of these results to those obtained with the antibiotics, with added evidence of the production of ${ }^{14} \mathrm{CO}_{2}$, shows, by similar arguments to those given above, that no step after the initial uptake reaction was inhibited by galactose. Measurements of the size of the glucose pool in the protozoa by the method of Huggett \& Nixon (1957) were also undertaken, to show that the results 
obtained were not caused by large changes in the size of the pool during the experiment. It was found that the glucose taken up accounted for less than $10 \%$ of the glucose pool, and that the size did not change significantly over the course of a $3 \mathrm{~h}$ incubation. These results, therefore, confirm the conclusion reached in the experiments with the antibiotics, that the intracellular bacteria only metabolized glucose that had already been taken up by the protozoa.

As with the uptake of amino acids, there are probably two mechanisms for the uptake of $\left[{ }^{14} \mathrm{C}\right]$ glucose by Entodinium simplex. This is suggested by a discontinuity at $0.0 \mathrm{I}$ to $0.02 \mathrm{M}$ on a reciprocal plot of uptake of ${ }^{14} \mathrm{C}$ from $\left[{ }^{14} \mathrm{C}\right]$ glucose into both intact protozoa and the brokencell supernatant fluid thereof against substrate concentration, as was found for $E$. caudatum $($ Coleman, $1969 b$ ). There was also a discontinuity on a similar plot for incubations carried out in the presence of galactose, but, as shown in Table 5, galactose was more inhibitory at low glucose concentrations than at high. This suggested that, as was found for E. caudatum (Coleman, $1969 b$ ), the uptake may be 'active' at low concentrations and subject to inhibition by galactose. At high concentrations the uptake was probably 'passive' and could be the result of diffusion of the medium into some part of the protozoon from which it was not removed by washing; this process should not be inhibited by galactose.

To determine if the enzyme hexokinase was involved in the uptake process the effect of galactose on this enzyme was investigated by the method of Coleman (1969b). Under the conditions used for the experiment quoted in Table 5, galactose inhibited by $40 \%$ the conversion of glucose to hexose phosphate in the presence of adenosine triphosphate. As this was much less than the inhibition by galactose of uptake of glucose into the protozoa, hexokinase is not thought to be involved in the uptake process.

\section{DISCUSSION}

Entodinium simplex is one of the most common rumen protozoa and in Clun Forest sheep fed on hay and oats at Babraham accounted, on a numerical basis, for 70 to $80 \%$ of the protozoa present. It was not possible to grow this protozoon in vitro as easily as $E$. caudatum and only a much smaller weight of organism could be harvested at any one time. As $E$. simplex required wholemeal flour for growth, instead of rice starch, washed preparations of this protozoon were always contaminated with plant material. These difficulties, and their greater sensitivity to oxygen, limited the investigations that could profitably be carried out with $E$. simplex. The object of this study was, therefore, to compare $E$. simplex with $E$. caudatum as far as was possible and to conclude on the basis of similar results that the same mechanism existed in both organisms, but without being able to prove its presence conclusively.

The results show that Entodinium simplex has similar metabolic capabilities to E. caudatum and utilizes carbohydrate as a source of energy and bacteria as a source of amino acids for protein synthesis. Both protozoa had little or no ability to synthesize amino acids from carbohydrate, although they were able to catabolize amino acids to a limited extent. This means that neither of these entodinia studied are of importance in the rumen in the biosynthesis of amino acids, unlike the bacteria which preferentially utilize ammonia rather than amino acids for the synthesis of protein (Bryant \& Robinson, I963). In animals on a restricted, high-grain ration the number of entodinia can rise to $2 \cdot 7 \times 10^{6} / \mathrm{ml}$, in the presence of $12.3 \times 10^{9}$ bacteria/ml (Eadie \& Mann, 1970), so that there are approximately equal masses of entodinia and bacteria in the rumen. It is therefore possible that, if these protozoal numbers are maintained throughout growth there could be a deficiency to the animal of 
those amino acids which are often present in low amounts in plant proteins. However, the finding that these entodinia release into their surroundings at least as much bacterial carbon as they retain, suggests that they are of importance in the turnover of amino acids etc. in the rumen, especially under the conditions quoted above. As the released material would be fermented by the bacteria to volatile fatty acids and ammonia (Hungate, 1966) this would result in a further loss of amino acids to the ruminant. Purser \& Moir (I966) and Christiansen, Kawashima \& Burroughs (1965) showed that ammonia levels were always higher in faunated than defaunated sheep. The advantage to the ruminant of the presence of protozoa, gained by their increased digestibility further down the alimentary tract compared with bacteria (McNaught, Owen, Henry \& Kon, 1954) may, therefore, be partially lost for this reason.

I wish to thank Dr P. Kemp for inserting permanent rumen cannulae into the sheep used to provide rumen fluid for the routine maintenance of the protozoa, the members of the Sub-Department of Chemical Microbiology, Biochemistry Department, University of Cambridge, for their helpful advice and criticism, and Mrs B. Barker, Miss J. I. Davies and Miss M. A. Cash for valuable technical assistance.

\section{REFERENCES}

BRYANT, M. P. \& RoBinson, I. M. (1963). Apparent incorporation of ammonia and amino acid carbon during growth of selected species of ruminal bacteria. Journal of Dairy Science 46, 150-154.

Christiansen, W. C., KaWashima, R. \& Burroughs, W. (1965). Influence of protozoa upon rumen acid production and live weight gains in lambs. Journal of Animal Science 24, 730-734.

Coleman, G. S. (1956). The dissimilation of amino acids by Rhodospirillum rubrum. Journal of General Microbiology 15, 248-256.

Coleman, G. S. (1958). Maintenance of oligotrich protozoa from sheep rumen in vitro. Nature, London I82, I I04-I IO5.

Coleman, G. S. (1960). Effect of penicillin on the maintenance of rumen oligotrich protozoa. Nature, London $187,518-520$.

Coleman, G. S. (1964). The metabolism of Escherichia coli and other bacteria by Entodinium caudatum. Journal of General Microbiology 37, 209-223.

Coleman, G. S. (1967a). The metabolism of free amino acids by washed suspensions of the rumen ciliate Entodinium caudatum. Journal of General Microbiology 47, 433-447.

Coleman, G. S. (1967b). The metabolism of the amino acids of Escherichia coli and other bacteria by the rumen ciliate Entodinium caudatum. Journal of General Microbiology 47, 449-464.

Coleman, G. S. (1968). The metabolism of bacterial nucleic acid and of free components of nucleic acid by the rumen ciliate Entodinium caudatum. Journal of General Microbiology 54, 83-96.

Coleman, G. S. (1969a). The cultivation of the rumen ciliate Entodinium simplex. Journal of General Microbiology $57,81-90$.

Coleman, G. S. (1969b). The metabolism of starch, maltose, glucose and some other sugars by the rumen ciliate Entodinium caudatum. Journal of General Microbiology 57, 303-332.

Coleman, G. S. \& Hall, F. J. (1969). Electron microscopy of the rumen ciliate Entodinium caudatum, with special reference to the engulfment of bacteria and other particulate matter. Tissue and Cell $\mathbf{r}, 607-618$.

EADIE, J. M. \& MANN, S. O. (I970). Development of the rumen microbial population: high starch diets and instability. In Physiology of Digestion and Metabolism in the Ruminant, pp. 335-347. Newcastle-uponTyne: Oriel Press.

Gutierrez, J., Williams, P. P., Davis, R. E. \& Warwick, E. J. (1962). Lipid metabolism of rumen ciliates and bacteria. I. Uptake of fatty acids by Isotricha prostoma and Entodinium simplex. Applied Microbiology 10, 548-55I.

Huggett, A. St G. \& Nixon, D. A. (1957). Use of glucose oxidase, peroxidase and $o$-dianisidine in the determination of blood and urinary glucose. Lancet ii, 368-370.

Hungate, R. E. (1966). The Rumen and its Microbes. New York and London: Academic Press.

JARVIS, B. D. W. \& HunGATE, R. E. (I968). Factors influencing agnotobiotic culture of the rumen ciliate Entodinium simplex. Applied Microbiology 16, 1044-1052. 
McNaught, M. L., Owen, E. C., Henry, K. M. \& Kon, S. K. (I954). The utilization of non-protein nitrogen in the bovine rumen. 8. The nutritive value of the proteins of preparations of dried rumen bacteria, rumen protozoa and brewers yeast for rats. Biochemical Journal 56, I 5 I-I 56.

PuRser, D. B. \& MoIR, R. J. (I966). Dietary effects upon concentrations of protozoa in the rumen. Journal of Animal Science 25, 668-674.

Roberts, R. B., Abelson, P. H., Cowie, D. E., Bolton, E. T. \& Britten, R. J. (1955). Studies on Biosynthesis in Escherichia coli. Publication of the Carnegie Institution 607. Washington: Carnegie Institution.

WHITE, R. W. (1969). Viable bacteria inside the rumen ciliate Entodinium caudatum. Journal of General Microbiology 56, 403-408.

Williams, P. P., GutierReZ, J. \& DAVIS, R. E. (1963). Lipid metabolism of rumen ciliates and bacteria. 2. Uptake of fatty acids and lipid analysis of Isotricha intestinalis and rumen bacteria with further information on Entodinium simplex. Applied Microbiology II, 260-264.

WyatT, G. R. (195I). The purine and pyrimidine composition of deoxypentose nucleic acid. Biochemical Journal 48, 584-590. 